\title{
Mucosal lesions of the gastric mucosa in adult patients with coeliac disease
}

\author{
Zmiany w błonie śluzowej żołądka u dorosłych chorych na celiakię
}

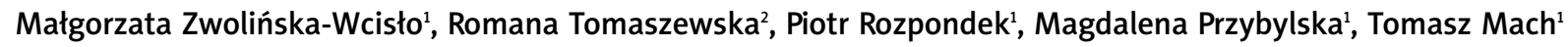 \\ 1Department of Gastroenterology, Hepatology and Infectious Diseases, Jagiellonian University Medical College, Krakow, Poland \\ 2Department of Clinical and Experimental Patomorphology, Jagiellonian University Medical College, Krakow, Poland
}

Prz Gastroenterol 2012; 7 (5): 291-298

DOI: $10.5114 /$ pg.2012.32068

Key words: coeliac disease, lymphocytic gastritis, dyspepsia.

Słowa kluczowe: celiakia, limfocytarne zapalenie żołądka, dyspepsja.

Address for correspondence: Małgorzata Zwolińska-Wcisło MD, PhD, Department of Gastroenterology, Hepatology and Infectious Diseases, Jagiellonian University Medical College, 5 Śniadeckich St, 31-531 Krakow, Poland, phone: +48 124247340 ,

e-mail: mzwcislo@su.krakow.pl

\begin{abstract}
Introduction: Coeliac disease is a chronic inflammatory disorder of the gastrointestinal tract, of autoimmune etiology, in genetically predisposed persons. The role of the gastric lesions and their influence on the clinical course of that disease have not been explained.

Aim: To evaluate the frequency of morphological lesions in the gastric mucosa in adults with coeliac disease and their effect on the clinical picture of gluten enteropathy.

Material and methods: Ninety patients, including 35 patients with coeliac disease and 55 with dyspeptic symptoms (control group) were examined. Clinical studies comprised history of disease, physical examination, blood tests and gastroscopies. Biopsies from the gastric and distal part of the duodenal mucosa were stained with haematoxylin-eosin, for estimation of the intensity of mucosal changes and a count of the intraepithelial lymphocytes (IEL). Immunohistochemical studies with anti-CD3 antibodies were performed for the identification of $\mathrm{CD}^{+}$+ lymphocytes.

Results: An increased number of IEL was observed in coeliac patients treated as well as not treated with gluten, compared with the control group. Lymphocytic gastritis (LG) was observed in $8.6 \%$ of coeliac patients. Patients with coeliac disease and LG presented intense dyspeptic symptoms. Presence of $\mathrm{CD}^{+} \mathrm{T}$ lymphocytes was revealed in the gastric and duodenal mucosa with immunohistochemical staining.

Conclusions: Morphological lesions in the gastric mucosa belong to gastroenteropathy in the course of coeliac disease and may induce dyspeptic symptoms. Taking biopsies from the distal part of the duodenum in patients with dyspeptic symptoms should be considered.
\end{abstract}

\section{Streszczenie}

Wstęp: Celiakia jest przewlekłą chorobą zapalną przewodu pokarmowego o podłożu autoimmunologicznym, występującą u osób predysponowanych genetycznie. Znaczenie zmian patologicznych w błonie śluzowej żołądka u chorych na celiakię i ich wpływ na przebieg kliniczny tej choroby nie zostały dotąd w pełni poznane.

Cel: Ocena częstości występowania zmian histopatologicznych w błonie śluzowej żołądka u dorosłych osób z celiakią oraz wpływu tych zmian na obraz kliniczny choroby.

Materiat i metody: Do badań włączono 90 pacjentów, w tym 35 chorych na celiakię i 55 osób z objawami dyspeptycznymi (grupa kontrolna). Obejmowały one wywiad chorobowy, badanie przedmiotowe, badania krwi oraz panendoskopię. Wycinki z błony śluzowej żołądka i części pozaopuszkowej dwunastnicy barwiono hematoksyliną i eozyną. Oceniano nasilenie zmian zapalnych oraz liczbę limfocytów śródnabłonkowych (intraepithelial lymphocytes - IEL). Za pomocą badania immunohistochemicznego z zastosowaniem przeciwciał monoklonalnych anty-CD3+ identyfikowano limfocyty $\mathrm{CD}^{+}$. Ocenę bioptatów z dwunastnicy w kierunku celiakii wykonano zgodnie z klasyfikacją Marsha.

Wyniki: U chorych na celiakię, zarówno nieleczonych, jak i leczonych dietą bezglutenową, obserwowano wzrost IEL, jednak ich liczba była znamiennie większa $u$ chorych niestosujących diety bezglutenowej. Limfocytarne zapalenie żołądka rozpoznano u $8,6 \%$ chorych na celiakię. Osoby te podawały nasilone dolegliwości dyspeptyczne. W badaniu immunohistochemicznym wykazano obecność nacieków limfocytów $\mathrm{T} \mathrm{CD3}^{+}$zarówno w bioptatach błony śluzowej żołądka, jak i części pozaopuszkowej dwunastnicy. 


\section{Introduction}

Coeliac disease (gluten enteropathy) is a chronic inflammatory disease of the gastrointestinal (Gl) tract of autoimmune aetiology, occurring in genetically predisposed persons. Hallmarks of coeliac enteropathy include an early rise of intestinal intraepithelial lymphocytes (IEL), followed by crypt hyperplasia and villous atrophy, in response to oral gluten intake [1].

Inflammatory lesions in the Gl tract of coeliac patients seem not to be confined to the small intestine. Gluten enteropathy may be a risk factor of development of lymphocytic gastritis (LG) [2]. The diagnostic threshold for LG is usually taken as greater than 25 IEL per 100 gastric columnar epithelial cells [3]. The significance of mucosal gastric lesions in coeliac patients and their influence on clinical course remain unexplained.

\section{Aim}

The aim of the studies was to evaluate the frequency of histological lesions in the gastric mucosa in coeliac patients, including the presence of $\mathrm{CD}^{+}$lymphocytes and their influence on the clinical picture of gluten enteropathy.

Table I. Characteristics of patients with coeliac disease and dyspepsia

Tabela I. Charakterystyka grup chorych na celiakię i pacjentów z dyspepsja

\begin{tabular}{|c|c|c|}
\hline Variable & Coeliac disease, $n$ & Dyspepsia, $n$ \\
\hline Number & 35 & 55 \\
\hline $\begin{array}{l}\text { Age, min-max, } \\
\text { mean } \pm \text { SD [years] }\end{array}$ & $18-72(30.8 \pm 8)$ & $18-72(41 \pm 7)$ \\
\hline Women & 20 & 29 \\
\hline Men & 15 & 26 \\
\hline CD not treated with GFD & 24 & 48 - Dyspepsia \\
\hline CD treated with GFD & 11 & $7-\mathrm{DU}$ \\
\hline Coexistent diseases & $\begin{array}{c}2 \text { - S Hashimoto } \\
3-\text { UC } \\
1-\text { L-Crohn D }\end{array}$ & $1-U C$ \\
\hline \multicolumn{3}{|c|}{$\begin{array}{l}C D \text { - coeliac disease, GFD - gluten-free diet, DU - duodenal ulcer, } \\
\text { S Hashimoto - Hashimoto struma, UC - ulcerative colitis, L-Crohn } \\
D \text { - Crohn's disease } \\
C D \text { - celiakia, GFD - dieta bezglutenowa, DU - choroba wrzodowa } \\
\text { dwunastnicy, S Hashimoto - wole Hashimoto, UC - wrzodziejace } \\
\text { zapalenie jelita grubego, L-Crohn D - choroba Leśniowskiego-Crohna }\end{array}$} \\
\hline
\end{tabular}

Wnioski: Zmiany morfologiczne błony śluzowej żołądka należą do obrazu gastroenteropatii glutenowej. Mogą im towarzyszyć objawy dyspeptyczne, nietypowe w tej chorobie. Autorzy proponują rozważenie pobierania wycinków z części pozaopuszkowej dwunastnicy u chorych z objawami dyspeptycznymi.

\section{Material and methods}

Patients from the Outpatient Clinic of the Department of Gastroenterology and Hepatology Jagiellonian University in Krakow, suffering from symptoms indicating malabsorption syndrome or dyspeptic symptoms, as well as patients with previously diagnosed coeliac disease, were included in the study.

They were informed about the subject of the above studies and expressed written consent to the studies. Clinical investigation comprised history of disease, including present complaints indicating coeliac disease, such as diarrhoea, microcytic anaemia, as well as dyspeptic symptoms including epigastric discomfort, early satiety, belching or nausea and physical examination.

Venous blood probes were taken for evaluation of the blood count, iron level and the titre of anti-transglutaminase (tTG) IgA antibodies in the serum.

Upper Gl tract endoscopy was performed for the evaluation of macroscopic lesions in the mucosa as well as for taking mucosal biopsies from the body and antral part of the stomach and the distal part of the duodenum. Also the urease test for Helicobacter pylori bacteria presence in the gastric mucosa was performed.

The diagnosis of coeliac disease was based on the clinical symptoms, evaluation of tTG IgA in the serum and histological assessment of the distal part of the duodenal mucosa. Patients with infections of the Gl tract, treated with non-steroidal anti-inflammatory drugs (NSAID) or glucocorticoids were excluded from the study.

Finally 90 patients, aged 18-72 years (average: 30.8 \pm 4.5 years), including 35 coeliac patients $(n=24$, patients with recent diagnosis of $C D, n=11$, patients with earlier diagnosis of $C D$ ) and 55 patients presenting dyspeptic symptoms $(n=48$, patients without significant lesions in the gastric and duodenal mucosa, $n=7$ with duodenal ulcers) as the control group were included. Additionally, in 6 coeliac patients and 1 in the control group, coexistence of autoimmune disorders was detected. Characteristics of examined groups are presented in Table I.

In the coeliac patients, a strict gluten-free diet was recommended. In patients with dyspeptic symptoms, a standard dose of proton pump inhibitor (PPI) was initiated.

Coeliac patients with LG underwent upper GI endoscopy after 6 months of gluten-free diet therapy, with 
biopsies being taken from the stomach and distal part of the duodenum for evaluation of the intensity of mucosal lymphocytic infiltrates.

\section{Histological evaluation}

Histological evaluation of mucosal lesions in the gastric mucosa stained with haematoxylin-eosin was performed according to the Sydney system, including normal appearance of gastric mucosa, chronic superficial gastritis (activity 0-3), follicular gastritis and atrophic gastritis [2].

The presence of $H$. pylori in the gastric mucosa was evaluated in the gastric mucosa biopsies, stained with haematoxylin-eosin and modified Giemsa method.

Histology of the mucosa of the distal part of the duodenum was expressed according to the Marsh classification, including: normal mucosa, type I: infiltrative lesions with more than 30 lymphocytes/100 epithelial cells, type II: infiltrative/hyperplastic lesions, type III: subdivided into partial (IIIA), subtotal (IIIB) and total (IIIC) villous atrophy [2, 4]. Type III is considered as the most characteristic for coeliac disease $[4,5]$.

Evaluation of the number of IEL in the biopsies from the body, antral part of the gastric mucosa and distal part of the duodenum stained with haematoxylin-eosin was performed. Fife hundred consecutive epithelial cells were examined. The number of lymphocytes per 100 epithelial cells was counted. Lymphocytic gastritis was said to be present when the number of mature intraepithelial lymphocytes was more than 25/100 gastric columnar epithelial cells [3].

For the identification of lymphocytes forming infiltrates in the gastric mucosa and the distal part of the duodenum, immunostaining was performed. AntiCD3+ monoclonal antibodies (pan T cell marker) (Dako,
High Wycombe, UK) at 1 in 50 dilution were used according to the method described by the producer.

\section{Statistical analysis}

Statistical analysis was performed using the program Statistica 8.0 (UJ license). Results were expressed as means \pm SEM. Statistical differences between examined groups were evaluated with the $\chi^{2}$ test. Differences at the level of $p<0.05$ were considered significant.

\section{Results}

\section{Clinical picture of patients with gluten enteropathy}

Among dyspeptic symptoms observed in the coeliac patients, early satiety in the epigastrium was observed more frequently in comparison with the control group, but the differences were not statistically significant (Table II).

In patients diagnosed with endoscopy because of dyspeptic complaints, symptoms indicating coeliac disease, such as diarrhoea (45\% of cases), microcytic anaemia (35\% of cases), osteoporosis (9\% of cases), loss of weight ( $20 \%$ of cases), as well as depression ( $4 \%$ of cases) were reported (Figure 1).

\section{Endoscopic picture of gastric mucosa in patients with gluten enteropathy}

Gastric mucosa in the coeliac patients as well as in the control group showed focal reddening and erosions in the antral part and in the distal part of the duodenum.

\section{Lymphocytic gastritis}

In the coeliac patients, both treated and not treated with a gluten-free diet, increase of the number of IEL was observed in the gastric mucosa. The mean IEL num-

Table II. Frequency of clinical symptoms in the examined groups of patients

Tabela II. Częstość występowania objawów klinicznych w badanych grupach

\begin{tabular}{lcccc} 
Symptoms & \multicolumn{4}{c}{ Groups of patients } \\
\cline { 2 - 5 } & $\mathrm{A}(n=28)$ & $\mathrm{B}(n=7)$ & $\mathrm{C}(n=33)$ & $\mathrm{D}(n=22)$ \\
\hline Epigastric satiety & $12(45 \%)$ & $3(43 \%)$ & $14(42 \%)$ & $9(41 \%)$ \\
\hline Belching & $6(22 \%)$ & $2(28 \%)$ & $3(9 \%)$ & $4(17 \%)$ \\
\hline Epigastric pain/discomfort & $14(50 \%)$ & $3(43 \%)$ & $14(42 \%)$ & $10(45 \%)$ \\
\hline Nausea & $6(21 \%)$ & $2(28 \%)$ & $6(18 \%)$ & $5(23 \%)$ \\
\hline Pyrosis & $7(25 \%)$ & $1(14 \%)$ & $7(21 \%)$ & $6(27 \%)$ \\
\hline Diarrhoea & $19(68 \%)$ & $4(57 \%)$ & $5(15 \%)$ & $4(18 \%)$
\end{tabular}

$A$ - coeliac disease and H. pylori infection, B - coeliac disease without H. pylori infection, $C-d y s p e p s i a$ and $H$. pylori infection, D - dyspepsia without H. pylori infection

A - z celiakią i infekcją H. pylori, B - z celiakią bez infekcji H. pylori, $C-z$ dyspepsją czynnościową i infekcją H. pylori, D-z dyspepsją czynnościowa bez infekcji $\mathrm{H}$. pylori 


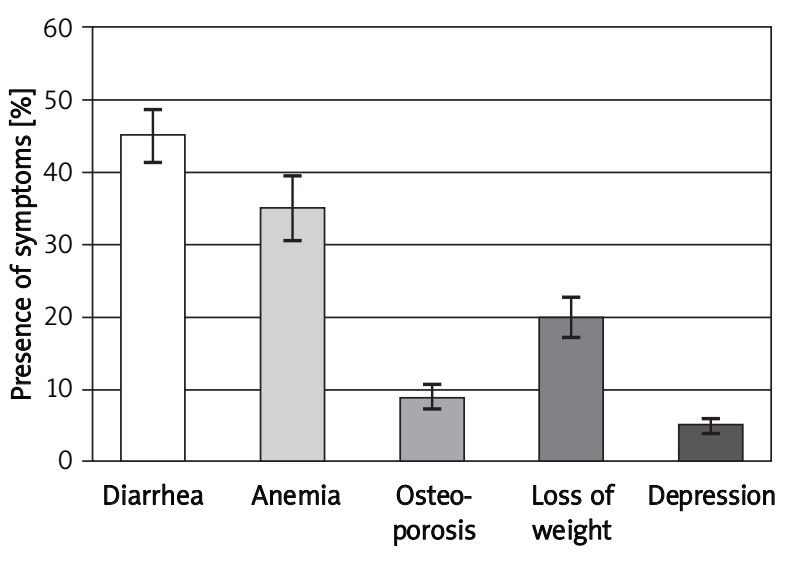

Fig. 1. Presence of symptoms indicating malabsorption syndrome in patients with dyspepsia or reflux disease, examined with endoscopy

Ryc. 1. Występowanie symptomów wskazujacych na zespót upośledzonego wchłaniania u chorych, którym wykonano endoskopię z powodu objawów dyspeptycznych lub refluksowych

ber in the gastric mucosa of patients not treated with the gluten-free diet was $9.2 \pm 0.5$ and it was significantly higher than the IEL number in the control group $(4.2 \pm 0.4)(p<0.05)$ (Table III).

Three coeliac patients ( $8.6 \%$ of cases) and one in the control group fulfilled criteria of LG, which means that the IEL number exceeded 25 per 100 epithelial cells (Table III).

In all these cases, coeliac disease was diagnosed for the first time. Patients with gluten enteropathy and diagnosed LG suffered from intensive dyspeptic symptoms, mainly epigastric pain or discomfort, nausea, and pyrosis. Also, symptoms indicating malabsorption, such as microcytic anaemia, loss of weight or diarrhoea, were observed (Table IV). Endoscopic evaluation revealed focal reddening and mosaic structure in the body or antral part of the gastric mucosa (Figures 2 A, B). Thinning of the circular folds and mosaic surface of the distal part of the duodenum was also observed (Figure $2 \mathrm{C}$ ).

Haematoxylin-eosin staining revealed lymphocytes in the superficial epithelium and in the gastric foveolae of the body and antral part of the stomach, proportion from $1: 3$ to $1: 2$, focal $1: 1$ (Figures $3 \mathrm{~A}, 4 \mathrm{~A}$ ).

Lymphocytic gastritis in the coeliac patients coexisted with partial (1 patient) or total villous atrophy ( 2 patients) in the distal part of the duodenum, according to grade III $B$ and III $C$ of the Marsh scale respectively (Figures $5 \mathrm{~A}, 6 \mathrm{~A}$ ).

Helicobacter pylori infection was detected in one patient in this group. In addition, gastric mucosal lesions corresponding with LG were found in one patient presenting dyspeptic symptoms from the control group, with previously diagnosed ulcerative colitis.

Immunohistology showed in patients with LG the presence of $\mathrm{CD}^{+} \mathrm{T}$ lymphocytes, both in the gastric mucosa and in the distal part of the duodenum mucosal biopsies, giving evidence for the connection of lesions observed in the stomach and the duodenum in coeliac disease (Figures 3 B, 4 B, 5 B, 6 B).

Application of the gluten-free diet in the coeliac patients with LG caused the disappearance of dyspeptic symptoms, not responding to the previous PPI treatment. In 2 cases a decrease of IEL number in the gastric mucosa in the control histological evaluation after 6 months was observed.

\section{Discussion}

Association of coeliac disease with histological lesions in the gastric mucosa has not been fully explained. The results of our studies revealed the presence of $L G$ in $8.6 \%$ of coeliac patients.

Table III. Histological lesions in the gastric mucosa in coeliac patients and controls

Tabela III. Zmiany histopatologiczne w błonie śluzowej żołądka u chorych na celiakię i w grupie kontrolnej pacjentów z dyspepsja

\begin{tabular}{|c|c|c|c|}
\hline \multirow[t]{3}{*}{ Lesions } & \multicolumn{3}{|c|}{ Groups of patients } \\
\hline & \multicolumn{2}{|c|}{$\mathrm{CD}(n=35)$} & \multirow[t]{2}{*}{ Dyspepsia $(n=55)$} \\
\hline & Not treated with GFD & Treated with GFD & \\
\hline Normal gastric mucosa & 0 & & 0 \\
\hline Chronic superficial gastritis & $16(67 \%)$ & $5(55 \%)$ & $38(69 \%)$ \\
\hline Mean IEL in the gastric mucosa & $9.2 \pm 0.5$ & $6.3 \pm 0.4$ & $4.2 \pm 0.4 \%$ \\
\hline$L G$ & $3(8.6 \%)$ & & $1(1.8 \%)$ \\
\hline Helicobacter pylori infection & $7(20 \%)$ & 0 & $30(55 \%)$ \\
\hline
\end{tabular}

$C D$ - coeliac disease, GFD - gluten-free diet, $L G$ - lymphocytic gastritis

$C D$ - celiakia, GFD - dieta bezglutenowa, LG - limfocytarne zapalenie żołądka 
Table IV. Results of clinical and histological studies in patients with coeliac disease and dyspepsia with lymphocytic gastritis

Tabela IV. Wyniki badań klinicznych i histopatologicznych u chorych na celiakię lub z dyspepsją, z limfocytarnym zapaleniem błony śluzowej żołądka

\begin{tabular}{|c|c|c|c|c|c|c|c|}
\hline Patient & Age/sex & Symptoms & $\begin{array}{l}\text { Endoscopic } \\
\text { lesions }\end{array}$ & $\begin{array}{l}\text { Histology of } \\
\text { gastric mucosa }\end{array}$ & $\begin{array}{l}\text { Helicobacter } \\
\text { pylori }\end{array}$ & $\begin{array}{l}\text { Histology of duodenal } \\
\text { mucosa }\end{array}$ & $\begin{array}{l}\text { Coexisting } \\
\text { diseases }\end{array}$ \\
\hline 1 & $57 / F$ & $\begin{array}{c}\text { Abdominal pain, } \\
\text { diarrhoea } \\
\text { loss of weight }\end{array}$ & $\begin{array}{c}\text { Reddening, } \\
\text { mosaic surface }\end{array}$ & $\begin{array}{l}\text { Chronic gastritis, } \\
\text { non-active, } \\
\text { moderate degree, } \\
\text { focal pancreatic } \\
\text { metaplasia }\end{array}$ & 0 & Marsh III C & 0 \\
\hline 2 & $33 / F$ & $\begin{array}{l}\text { Epigastric pain, } \\
\text { pyrosis, anaemia }\end{array}$ & $\begin{array}{l}\text { Reddening, } \\
\text { mosaic surface }\end{array}$ & $\begin{array}{l}\text { Chronic gastritis, } \\
\text { non-active, } \\
\text { moderate degree }\end{array}$ & 0 & III C & 0 \\
\hline 3 & $28 / M$ & $\begin{array}{l}\text { Epigastric discomfort } \\
\text { Nausea, anaemia }\end{array}$ & $\begin{array}{l}\text { Reddening, } \\
\text { antral erosions }\end{array}$ & $\begin{array}{c}\text { Chronic gastritis, } \\
\text { non-active, } \\
\text { foveolar hyperplasia }\end{array}$ & + & III B & $\begin{array}{l}\text { Hashimoto } \\
\text { struma }\end{array}$ \\
\hline 4 & $41 / M$ & Epigastric discomfort & Reddening & $\begin{array}{l}\text { Chronic gastritis, } \\
\text { low degree }\end{array}$ & + & Normal & UC \\
\hline
\end{tabular}

$F$-female, $M$ - male, UC-ulcerative colitis

F-kobieta, M - mężczyzna, UC - wrzodziejące zapalenie jelita grubego

All coeliac patients with LG were not treated with the gluten-free diet previously and presented symptoms of malabsorption as well as dyspeptic complaints, making the main indication for the diagnosis of the upper GI tract. The results of our studies are similar to the data of $10 \%$ frequency of LG in coeliac patients, reported by Feeley et al. [3]. The results of other authors were divergent and ranged from $4 \%$ to $38 \%$ frequency of $L G$ in coeliac patients $[6,7]$. Dyspeptic symptoms were also reported by Usai et al. [8]. They could originate from formation of lymphocytic infiltrates, followed by impairment of the gastric mucosal barrier and gastric functional disorder.

Clinical symptoms were accompanied by non-specific endoscopic lesions in the gastric mucosa, such as
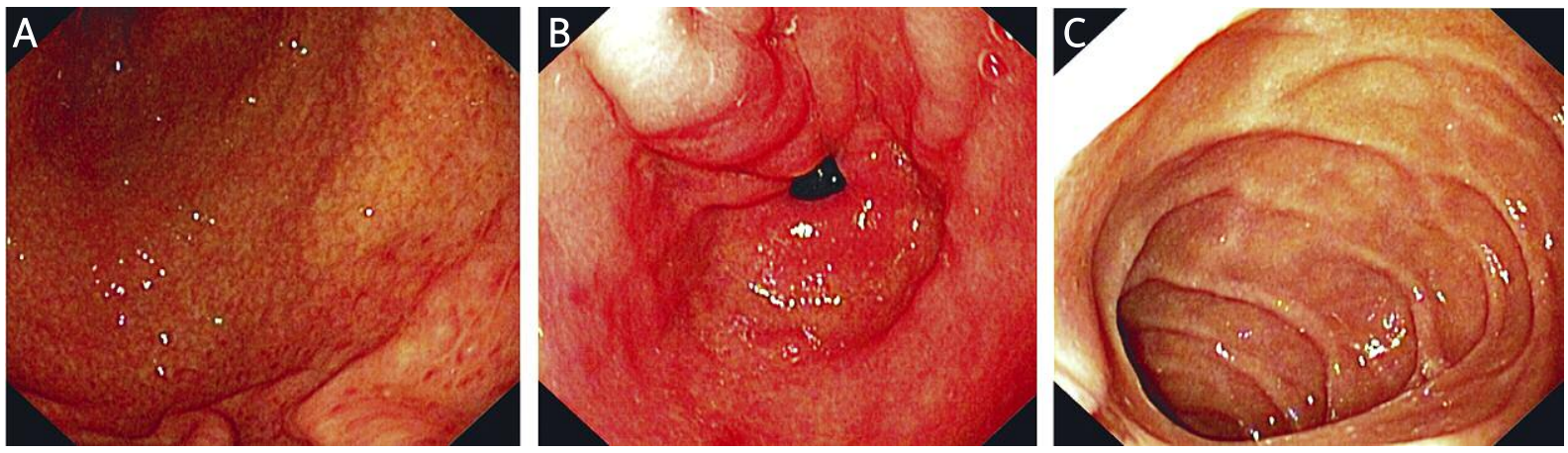

Fig. 2. A - Endoscopic picture of the body of the stomach in patients with diagnosed with coeliac disease and lymphocytic gastritis. Reddening and mosaic surface of the mucosa. B - Endoscopic picture of the antral part of the stomach in patients with diagnosed coeliac disease and lymphocytic gastritis. Reddening and the fold deforming pyloric region. C - Endoscopic picture of the distal part of the duodenum in patients with diagnosed coeliac disease. Thinning of the circular folds and mosaic surface of the distal part of the duodenum

Ryc. 2. A - Obraz endoskopowy trzonu żołądka u chorego na celiakię i z rozpoznanym limfocytarnym zapaleniem żołądka. Zaczerwienienie i mozaikowa powierzchnia błony śluzowej. B - Obraz endoskopowy części antralnej żołądka u chorego na celiakię i z rozpoznanym limfocytarnym zapaleniem żołądka. Dwubarwność błony śluzowej i fałd deformujący odźwiernik. C - Obraz endoskopowy części pozaopuszkowej dwunastnicy. Ścieńczenie fałdów okrężnych błony śluzowej. Zaznaczona mozaikowa powierzchnia błony śluzowej części pozaopuszkowej dwunastnicy 

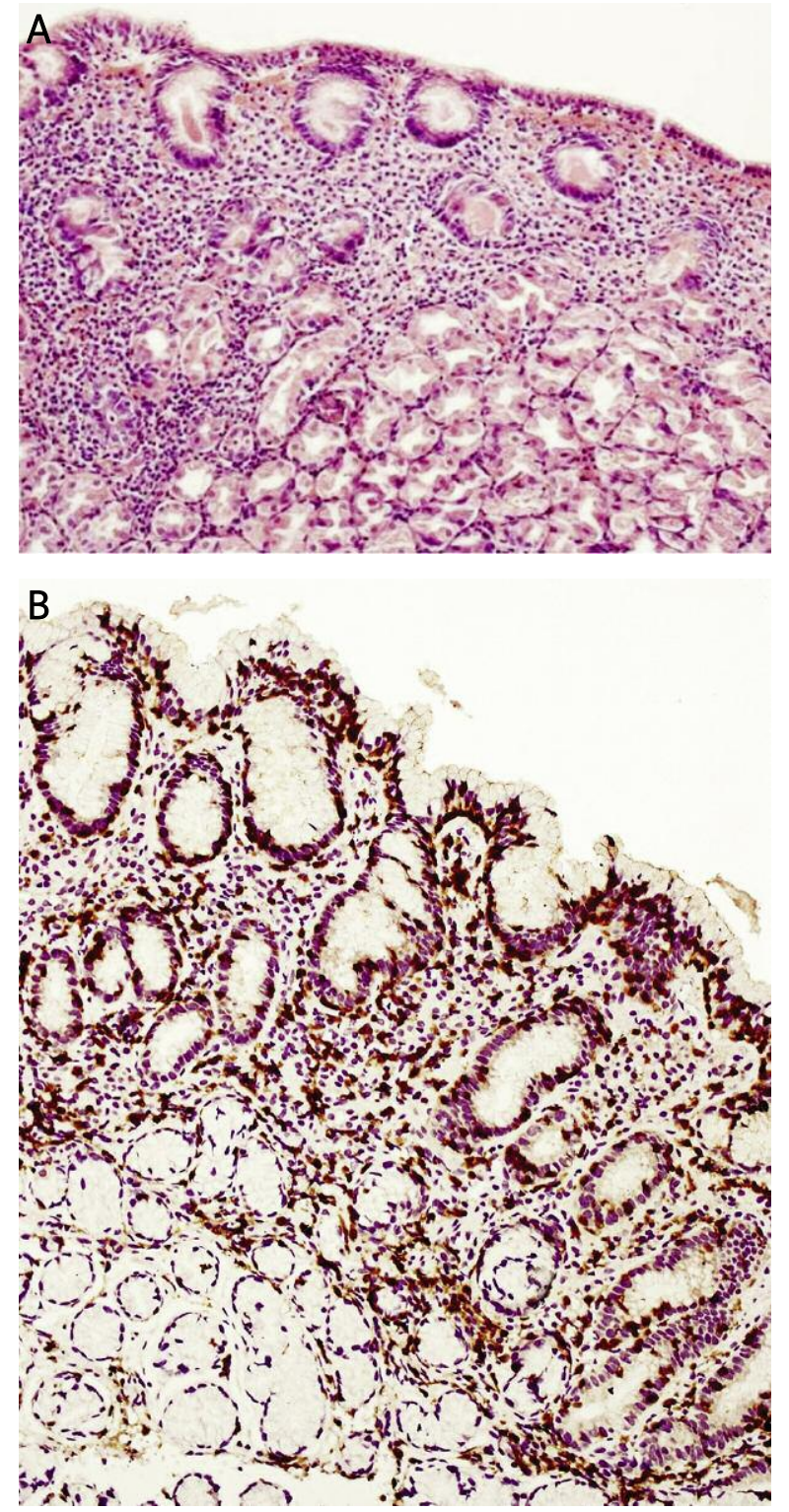

Fig. 3. A - Histological changes in the body of the stomach. Haematoxylin-eosin staining. Lymphocytic gastritis. Lymphocytes in the superficial epithelium and in the gastric foveolae of the body of the stomach, proportion $1: 3$, focal $1: 1$. B - Immunohistochemical reaction in the body of the gastric mucosa. CD3+ lymphocytic infiltrates

Ryc. 3. A-Zmiany histopatologiczne w błonie śluzowej trzonu żołądka. Barwienie hematoksylina i eozyna. Limfocytarne zapalenie żołądka. Limfocyty w nabłonku powierzchni i dołeczkach błony śluzowej trzonu żołądka w proporcji 1 : 3, ogniskowo 1 : 1. B - odczyn immunohistochemiczny $w$ błonie śluzowej trzonu żołądka. Nacieki limfocytów CD3+

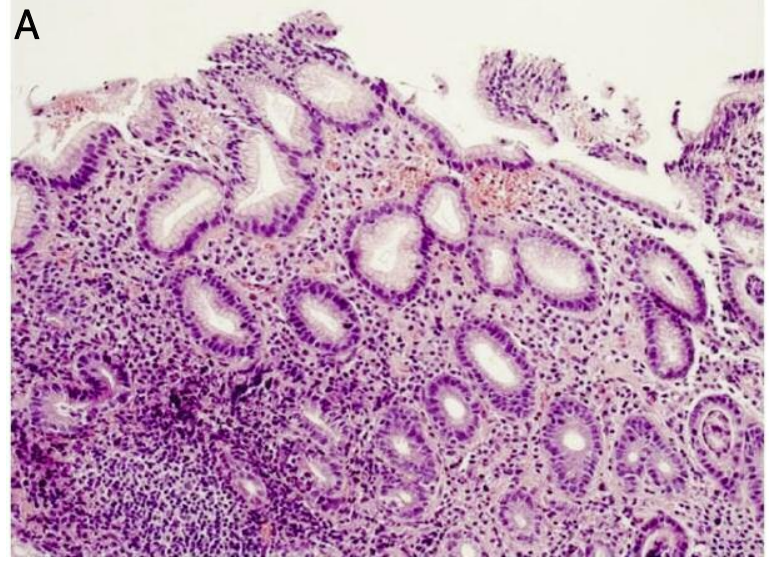

B

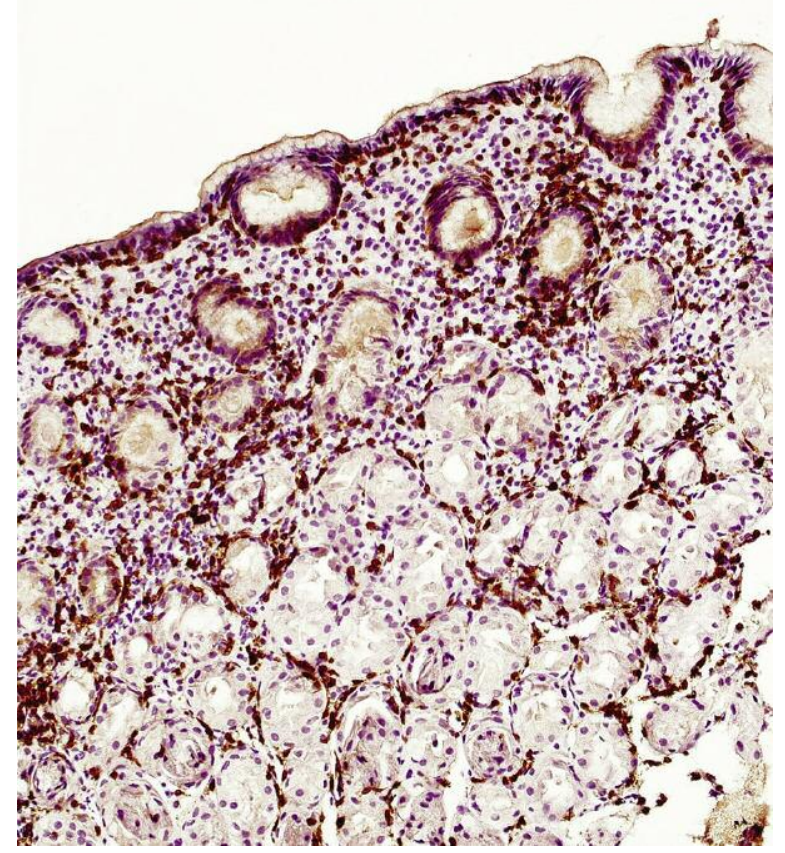

Fig. 4. A - Histological changes in the antral part of the gastric mucosa. Haematoxylin-eosin staining. Lymphocytic gastritis. Lymphocytes in the superficial epithelium and in the gastric foveolae of the body of the stomach, proportion $1: 2$, focal $1: 1$. B - Immunohistochemical reaction in the antral part of the gastric mucosa. CD3+ lymphocytic infiltrates

Ryc. 4. A - Zmiany histopatologiczne $w$ błonie śluzowej okolicy antralnej żotądka. Barwienie hematoksylina i eozyną. Limfocytarne zapalenie żołądka. Limfocyty w nabłonku powierzchni i doteczkach błony śluzowej trzonu żoładka w proporcji 1 : 2, ogniskowo $1: 1$. B-Odczyn immunohistochemiczny $w$ błonie śluzowej okolicy antralnej żołądka. Nacieki limfocytów CD3+ 


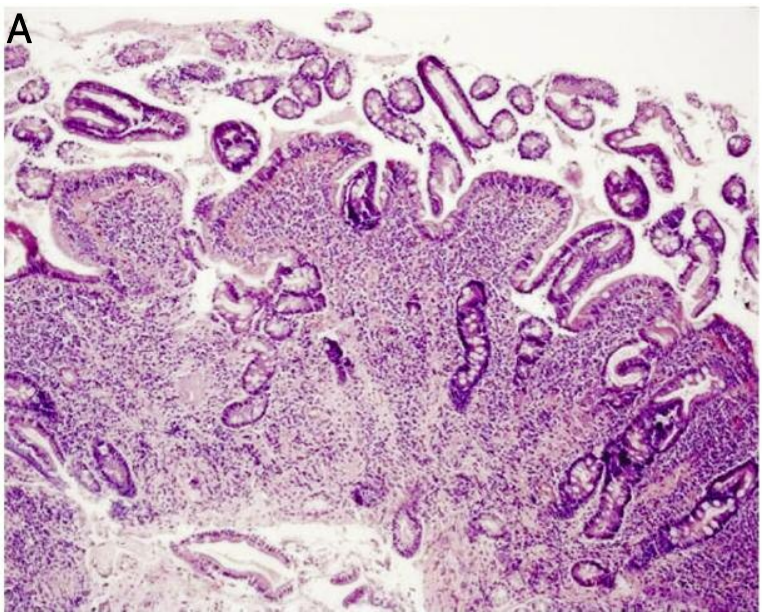

B

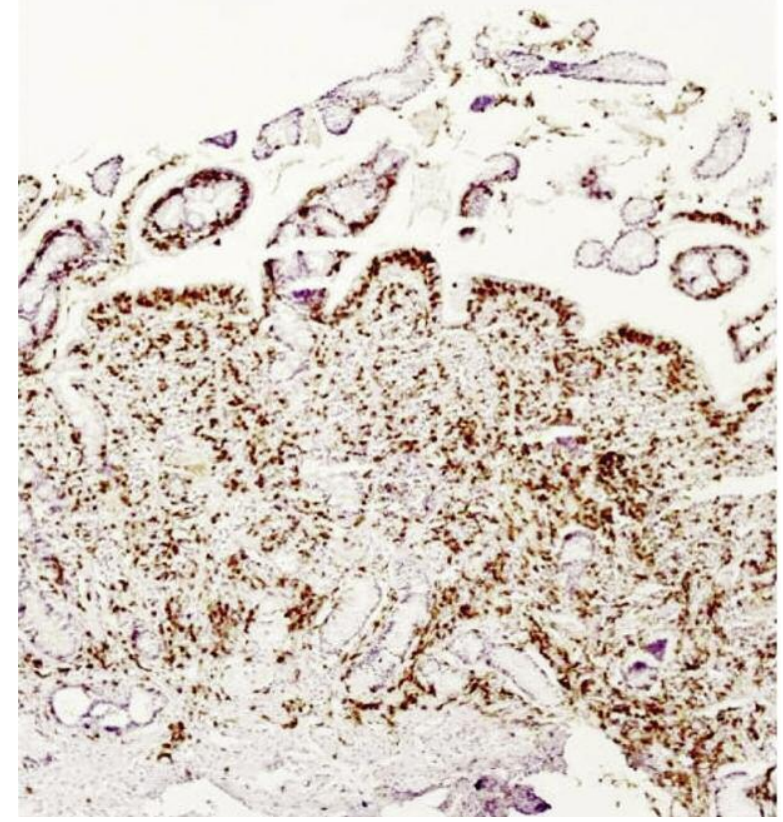

Fig. 5. A - Histological changes in the mucosa of the distal part of the duodenum (Marsh III B). Haematoxylin-eosin staining. Partial villous atrophy. CD3+ lymphocytic infiltrates. B - Immunohistochemical reaction in the mucosa of the distal part of the duodenum. Partial villous atrophy. CD3+ lymphocytic infiltrates

Ryc. 5. A - Zmiany histopatologiczne $w$ błonie śluzowej części pozaopuszkowej dwunastnicy. Barwienie hematoksylina i eozyną. Częściowy zanik kosmków jelitowych (stopień III B według Marsha). Widoczne nacieki limfocytarne. B-Odczyn immunohistochemiczny $w$ błonie śluzowej części pozaopuszkowej dwunastnicy. Częściowy zanik kosmków jelitowych. Nacieki limfocytów $\mathrm{CD} 3+$

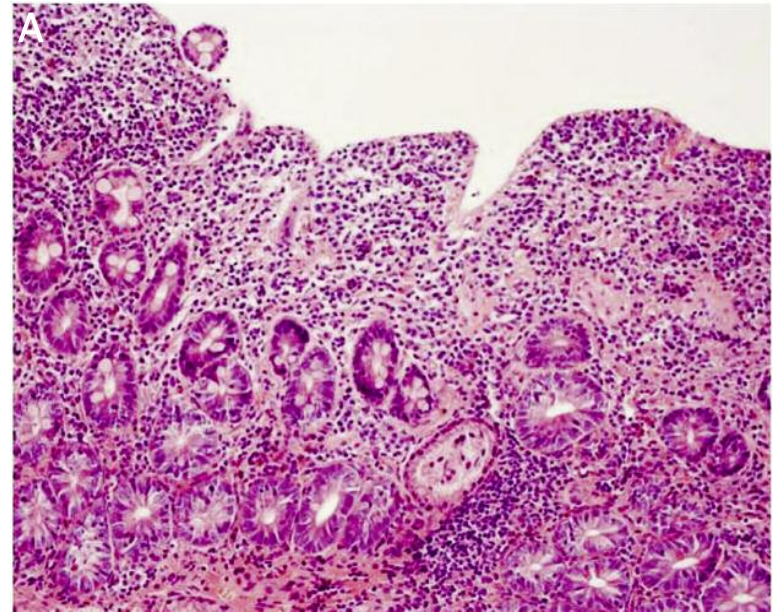

B

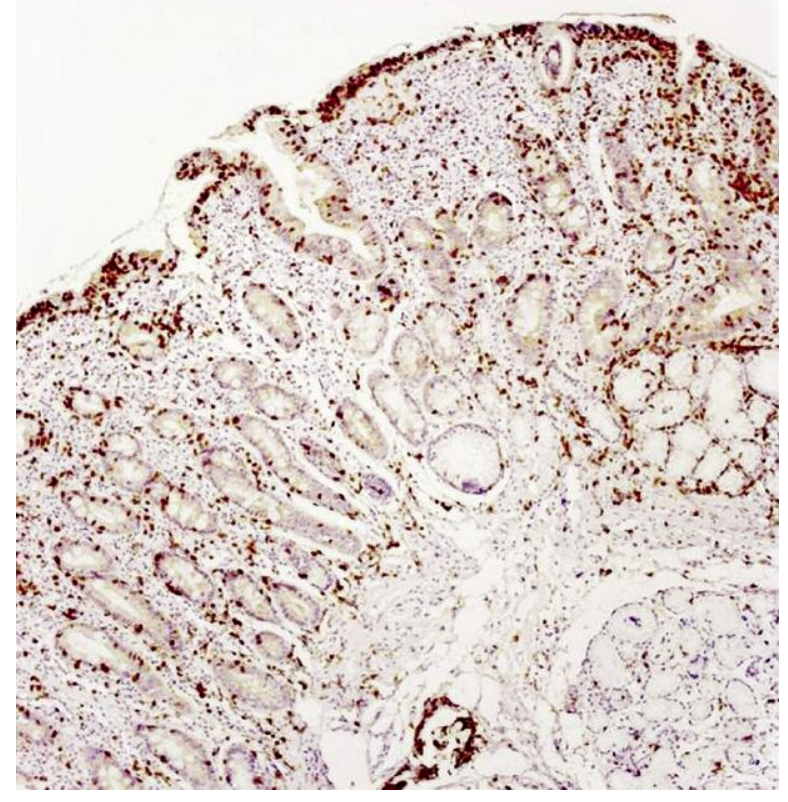

Fig. 6. A - Histological changes in the mucosa of the distal part of the duodenum. Haematoxylin-eosin staining. Total villous atrophy (Marsh III C). CD3+ lymphocytic infiltrates. B - Immunohistochemical reaction in the mucosa of the distal part of the duodenum. Total villous atrophy. CD3+ lymphocytic infiltrates

Ryc. 6. A - Zmiany histopatologiczne $w$ błonie śluzowej części pozaopuszkowej dwunastnicy. Barwienie hematoksylina i eozyna. Catkowity zanik kosmków jelitowych (stopień III C według Marsha). Widoczne nacieki limfocytarne. B - Odczyn immunohistochemiczny $w$ błonie śluzowej części pozaopuszkowej dwunastnicy. Catkowity zanik kosmków jelitowych. Nacieki limfocytów CD3+ 
reddening, mosaic surface or erosions. Mucosal lesions typical for LG, such as gastritis varioliformis, including aphthoid erosions, papular lesions or thickening of mucosal folds, described by other authors, were not observed in our patients [3].

In all examined coeliac patients, an increased number of IEL was observed, but did not fulfil the criterion of LG with the exception of 3 cases. The increased number of IEL could be the result of the autoimmune reaction in the course of coeliac disease or the direct contact of gluten with the mucosal barrier in the stomach in persons with hypersensitivity to this antigen $[3,6]$. Immunohistology of the gastric and duodenal mucosa biopsies revealed that lymphocytic infiltrates in both regions were formed by $\mathrm{CD}^{+} \mathrm{T}$ lymphocytes, suggesting that coeliac disease is an example of diffuse $T$ lymphocyte gastroenteropathy.

As previous results revealed, LG could be the manifestation of $H$. pylori infection [9]. The results of our studies showed the frequency of $H$. pylori in the gastric mucosa of coeliac patients and in the control group as $20 \%$ and $55 \%$ respectively, which was lower than the results reported by other authors, $82 \%$ and $97 \%$ respectively [2].

The explanation for lower $H$. pylori frequency in the examined group could be successful eradication therapy performed in patients with relapsing dyspeptic symptoms.

The above study showed the presence of LG in the coeliac patients, with or without $H$. pylori infection, which may suggest that these bacteria and the gluten enteropathy are independent factors inducing the rise of IEL number in the gastric mucosa. Application of the gluten-free diet caused regression of dyspeptic symptoms, accompanied by a fall of the IEL number in the gastric mucosa, in the control histological evaluation after 6 months. It suggests the significant role of lymphocytic infiltrates in the gastric mucosa in inducing dyspeptic symptoms in the coeliac patients.

In one dyspeptic patient from the control group, fulfilling the criterion of LG, ulcerative colitis was diagnosed previously. The association between LG and ulcerative colitis could be explained by the involvement of Th2 lymphocytes in the immunological response with the subsequent IL-5 and IL-10 cytokine mucosal expression [10].

A full explanation of the role of histological lesions in the gastric mucosa needs further studies in a more numerous group of patients.

\section{Conclusions}

Lymphocytic gastritis including CD3+ T lymphocytes in the gastric and the distal part of duodenal mucosa belongs to the picture of gluten enteropathy. Dyspeptic symptoms, observed in some of the coeliac patients, besides typical symptoms indicating malabsorption syndrome, may have an association with intraepithelial lymphocytosis. Taking biopsies from the distal part of the duodenum, from patients presenting dyspeptic symptoms, during gastroscopy, may contribute to the diagnosis of coeliac disease in some of them.

\section{Acknowledgments}

The research was financed from a grant: K/ZDS/ 001599.

\section{References}

1. Leon F, Sanchez L, Camarero C, et al. Cytokine production by intestinal intraepithelial lymphocyte subsets in celiac disease. Dig Dis Sci 2005; 50: 593-600.

2. Santarelli L, Gabrielli M, Santoliquido A, et al. Interaction between Helicobacter pylori infection and untreated coeliac disease on gastric histological pattern. Scand J Gastroenterol 2006; 41: 532-5.

3. Feeley KM, Heneghan MA, Stevens FM, et al. Lymphocytic gastritis and celiac disease: evidence of positive association. J Clin Pathol 1998; 51: 207-10.

4. Marsh MN. Studies of intestinal lymphoid tissue. The immunopathology of cell-mediated reactions in gluten sensitivity and other enteropaties. Scanning Microsc 1988; 2: 1663-84.

5. Sanders DS, Hurlstone DP, Brown S. Does celiac disease affect colorectal practice? Int J Colorectal Dis 2007; 22: 565-70.

6. Stancu M, De Petris G, Palumbo TP, et al. Collagenous gastritis associated with lymphocytic gastritis and celiac disease. Arch Pathol Med 2001; 125: 1579-84.

7. Leung ST, Chandan VS, Murray JA, et al. The collagenous gastritis. Histopathologic features and association with other gastrointestinal diseases. Am J Surg Pathol 2009; 33: 788-98.

8. Usai P, Satta P, Lai M, et al. Autonomic dysfunction and upper digestive functional disorders in untreated adult celiac disease. Eur J Clin Invest 1997; 27: 1009-15.

9. Lynch DAF, Sobala GM, Dixon MF, et al. Lymphocytic gastritis and associated small bowel disease: a diffuse lymphocytic gastroenteropathy? J Clin Pathol 1995; 45: 939-45.

10. Bouma G, Strober W. The immunological and genetic basis of inflammatory bowel disease. Nat Rev Immunol 2003; 3: 521-33. 